\title{
Plant carbohydrate binding module enhances activity of hybrid microbial cellulase enzyme
}

\author{
Caitlin S. Byrt ${ }^{1,2}$, Ricky Cahyanegara ${ }^{2}$ and Christopher P. L. Grof ${ }^{2 *}$ \\ ${ }^{\prime}$ Australian Research Council Centre of Excellence in Plant Cell Walls, Waite Campus, University of Adelaide, Adelaide, SA, Australia \\ ${ }^{2}$ School of Environmental and Life Sciences, University of Newcastle, Newcastle, NSW, Australia
}

\section{Edited by:}

Soren K. Rasmussen, University of Copenhagen, Denmark

Reviewed by:

Takashi Hashimoto, Nara Institute of Science and Technology, Japan

Chung-Jui Tsai, University of Georgia, USA

${ }^{*}$ Correspondence:

Christopher P. L. Grof, School of

Environmental and Life Sciences, University of Newcastle, University

Drive, Callaghan, Newcastle, NSW 2308, Australia.

e-mail: chris.grof@newcastle.edu.au
A synthetic, highly active cellulase enzyme suitable for in planta production may be a valuable tool for biotechnological approaches to develop transgenic biofuel crops with improved digestibility. Here, we demonstrate that the addition of a plant derived carbohydrate binding module (CBM) to a synthetic glycosyl hydrolase improved the activity of the hydrolase in releasing sugar from plant biomass. A CEL-HYB1-CBM enzyme was generated by fusing a hybrid microbial cellulase, CEL-HYB1, with the CBM of the tomato (Solanum lycopersicum) SICel9C1 cellulase. CEL-HYB1 and CEL-HYB1-CBM enzymes were produced in vitro using Pichia pastoris and the activity of these enzymes was tested using carboxymethylcellulose, MUC, and native crystalline cellulose assays. The presence of the CBM substantially improved the endoglucanase activity of CEL-HYB1, especially against the native crystalline cellulose encountered in Sorghum bicolor plant cell walls. These results indicate that addition of an endogenous plant derived CBM to cellulase enzymes may enhance hydrolytic activity.

Keywords: cellulase binding module, cellulose, endoglucanase, exo-glucanase, glycosyl hydrolase

\section{INTRODUCTION}

Increasing the efficiency of enzymatic hydrolysis of cellulose is a key challenge in the process of reducing the cost of producing transport fuels from lignocellulosic biomass (Cheng et al., 2011). Cellulase enzymes are required for cellulose hydrolysis because the $\beta-1,4$ linkage between glucose molecules in cellulose is a very stable bond that has a half-life of approximately five to eight million years at room temperature (Wolfenden and Snider, 2001). One factor influencing the efficiency of hydrolysis is the interaction of soluble cellulase enzymes with the insoluble cellulose (Cheng et al., 2011). Cellulase enzymes belong to different families of glycoside hydrolases (GHs). Many cellulases contain a catalytic domain $(\mathrm{CD})$ and a cellulose binding domain or module (Linder and Teeri, 1997); these are connected by a Pro/Ser/Thr rich linker (Batista et al., 2011). Other domains may also be present and these were recently described for bacterial cellulases in a comprehensive genome analysis (Medie et al., 2012).

There are three types of cellulase enzymes; endo- $\beta-1,4-$ glucanases (EC 3.2.1.4), exo- $\beta$-1,4-glucanases (EC 3.2.1.91, cellobiohydrolases), and $\beta$-glucosidases (EC 3.2.1.21; Taylor et al., 2008). Endo- $\beta$-1,4-glucanases cleave the $\beta-1,4$ bond between glucose residues in cellulose microfibrils randomly, whereas cellobiohydrolase hydrolyzes the bond at the reducing or non-reducing end of the polymer. Cellobioses are the product of the reaction catalyzed by these enzymes. The $\beta$-glucosidase cleaves cellobioses to produce monosaccharides that are fermentable by S. cerevisiae to produce ethanol (Louime and Uckelmann, 2008).

Carbohydrate binding modules (CBMs) target an enzyme to a specific component of the cell wall (Medie et al., 2012) and the hydrolysis of cellulose by a cellulase enzyme is initiated by the interaction of the cellulose binding module with the cellulose fiber (Caparrós et al., 2012). CBMs facilitate binding of the CD but they are not required for processivity; thus, they may increase activity of an enzyme on crystalline substrates but rarely increase activity on substrates such as carboxymethylcellulose (CMC) (Wilson, 2012).

There are three different states in which an enzyme with a CD and CBM may exist in the presence of crystalline substrate. The enzyme may be free in solution, the CBM may be bound but the $\mathrm{CD}$ unbound or both the CBM and the CD may be bound (Kostylev et al., 2011). The most common state is where the CBM is bound and the CD is unbound (Kostylev et al., 2011). This indicates that the binding of the enzyme via the CBM and the initial cleavage are two distinct events (Kostylev et al., 2011).

Carbohydrate binding modules may affect the thermostability of the $\mathrm{CD}$ activity, enabling enzymes to maintain activity at high temperatures (Mingardon et al., 2011). Three of the amino acid residues that are important for the thermostability activity of CBMs were identified in a recent study by using site-directed mutagenesis of a Bacillus sp. family 9 endoglucanase with a family 3 CBM (Yin et al., 2011). These residues may form hydrophobic stacking interactions with non-polar sugar rings of substrates; thus, the flexibility of the covalent link between the CBM and CD, and the polarity of this linkage is important (Yin et al., 2011).

\section{GENETIC ENGINEERING OF CBM}

Cellulase enzymes may provide solutions for industrial applications such as biomass processing for biofuels (Wilson, 2012) and detergency (Caparrós et al., 2012). Furthermore, the in planta expression of heterologous cellulase enzymes may reduce bioethanol production costs. Here we describe the addition of a plant derived CBM to a synthetic hybrid microbial glycosyl hydrolase enzyme that is codon optimized for expression in planta. 


\section{MATERIALS AND METHODS GENERATION OF THE SYNTHETIC GLYCOSYL HYDROLASE AND ISOLATION OF SLCEL9C1}

The CEL-HYB1 gene described by Xue et al. (2003) was synthesized by GENEART (GENEART gene synthesis service, Regensburg, Germany). CEL-HYB1 was then amplified to incorporate EcoRI and $P s t$ I restriction sites at the $5^{\prime}$ and $3^{\prime}$ end of the gene respectively. This product was ligated into the $\mathrm{pPICZ} \alpha \mathrm{A}$ vector and confirmed by sequencing.

RNA was extracted from 14-day-old S. lycopersicum cv Moneymaker hypocotyls using an RNeasy ${ }^{\circledR}$ Plant Mini Kit (Qiagen). First strand cDNA was synthesized from the isolated RNA using a QuantiTect ${ }^{\circledR}$ Reverse Transcription Kit (Qiagen). The cDNA encoding the cellulase SlCel9C1 (GenBank ID AF098292; see Urbanowicz et al., 2007) was amplified using the forward and reverse primers $5^{\prime}$-TTCCGTCGTTACAACCCG-3' ${ }^{\prime}$ and $5^{\prime}$ AGTTGCCCTTTGTTGAATAGT- $3^{\prime}$. The Pst I and Not I restriction sites were incorporated at the $5^{\prime}$ and $3^{\prime}$ ends of the amplicon respectively. A three-way ligation reaction fused the Pst I digested CBM encoding gene to the $3^{\prime}$ end of the Pst I digested CELHYB1. The fusion gene was inserted into the EcoRI-NotI site of the pPICZ $\alpha \mathrm{A}$ vector (Invitrogen). The pPICZ $\alpha \mathrm{A} \_C E L-H Y B 1$ and pPICZ $\alpha$ A_CEL-HYB1-CBM were linearized with PmeI and electroporated into Pichia pastoris (P. pastoris). Transformed cells were checked by colony PCR to confirm the presence of the respective vectors and positive clones were re-cultured for subsequent analysis.

\section{ENZYME PRODUCTION IN PICHIA PASTORIS}

The expression vector, pPICZ $\alpha \mathrm{A}$ (Invitrogen) directed the heterologous protein to be secreted using the $\alpha$-factor signal peptide and was tagged with both c-myc epitope and 6X histidine residues. Throughout the development of the constructs, PCR with appropriate primer sets was employed to amplify the required gene without the native signal peptides. The genes were then fused in frame with the $\alpha$-factor secretion signal. The signal peptide is removed by kex 2 and ste 13 proteases after it attaches to a receptor releasing mature protein. During the generation of the P. pastoris cell lines capable of producing the cellulase enzymes, PCR was performed to confirm the success of the yeast transformation procedure.

P. pastoris SMD1168 cells were grown on yeast peptone dextrose (YPD) solid media whereas electroporated cells were grown on YPD (YPDS) media supplemented with sorbitol and zeocin antibiotics $\left(100 \mu \mathrm{g} \mathrm{mL}^{-1}\right)$. The yeast cells were then incubated at $30^{\circ} \mathrm{C}$ for 3-4 days in the dark. P. pastoris cells used in protein overproduction were cultured in buffered glycerol-complex medium (BMGY) and buffered methanol complex medium (BMMY) at $30^{\circ} \mathrm{C}$ for 4 days whilst shaking at $250 \mathrm{rpm}$. Colonies transformed with the desired expression vectors (pPICZ $\alpha$ A_CEL-HYB1 and pPICZ $\alpha$ A_CEL-HYB1-CBM) were cultured in BMGY to $\mathrm{OD}_{600}$ of $2-6$ then collected cells were resuspended in $B M M Y$ to an $\mathrm{OD}_{600}$ of 1.0 and grown for a further 4 days. Induction was maintained by adding $100 \%$ methanol to a final concentration of $0.5 \%$ each day. Samples were collected prior to the induction and then 6,12 , $24,48,72$, and $96 \mathrm{~h}$ after induction. The culture was centrifuged and protein secreted into the culture medium was concentrated using Centricon Plus ${ }^{\circledR}-70$ columns (Millipore). Heterologous protein was detected by Western blot. Protein samples were separated electrophoretically ( $200 \mathrm{~V}$ for $30 \mathrm{~min}$ ) on a $10 \%$ SDS polyacrylamide gel. Protein bands on a replica gel were detected by staining with Coomassie Brilliant Blue stain [0.25\% (w/v); Methanol 20\% $(\mathrm{v} / \mathrm{v})$; Acetic acid $10 \%(\mathrm{v} / \mathrm{v})]$ and staining was then removed with Coomassie destain solution [Methanol 20\% (v/v); Acetic acid $10 \%(\mathrm{v} / \mathrm{v})]$. Separated proteins were transferred $\left(30 \mathrm{~V}\right.$ at $4^{\circ} \mathrm{C}$ overnight) onto a nitrocellulose HybondTM - C Extra membrane. The nitrocellulose membrane was washed with $1 \times$ TBST three times and blocked with $1 \times$ TBST/5\% skim milk/0.05\% Tween 20 solution for $1 \mathrm{~h}$. The blocked membrane was incubated for $1 \mathrm{~h}$ with a primary polyclonal antibody raised against a c-myc protein epitope in rabbit. The primary antibody was diluted 1:5000 in $1 \times \mathrm{TBST} / 5 \%$ skim milk/0.05\% tween 20 solution. The membrane was washed three times with $1 \times$ TBST and incubated with anti-rabbit secondary antibody conjugated to alkaline phosphatase (Sigma), diluted 1:5000, for $1 \mathrm{~h}$. The membrane was washed three times in $1 \times$ TBST solution and the band visualized with Western Blue ${ }^{\circledR}$ standard substrate for alkaline phosphatase (Promega). Recombinant protein was quantified using the Bradford protein assay and diluted appropriately for further assays.

\section{CMC AND MUC ASSAYS}

The CMC assay was modified from Ghose (1987) and Miller (1959). The recombinant cellulase enzyme was diluted to the required concentrations with $0.05 \mathrm{M}$ sodium citrate buffer at $\mathrm{pH}$ 6.0 in a volume of $500 \mu \mathrm{L}$ and incubated at the required temperature for $5 \mathrm{~min}$. Five hundred microliters of $2 \% \mathrm{CMC}$ was added and the sample incubated for a further $30 \mathrm{~min}$. Three milliliters of dinitrosalicylic acid (DNS) reagent was added and samples incubated at $100^{\circ} \mathrm{C}$ for $15 \mathrm{~min}$. One milliliter of $40 \%$ potassium sodium tartrate was added and then samples were diluted with $19 \mathrm{~mL}$ of Milli-Q water. The optical density of the samples was measured immediately at $540 \mathrm{~nm}$. This value was used to determine the concentration of cellulase required to release reducing sugar equivalent to $0.5 \mathrm{mg}$ of glucose. A D-glucose solution prepared at various concentrations was used as the standard. A blank was prepared by adding the enzyme to the substrate just prior to the heating step. The activity of the cellulase enzyme was expressed as $\mu \mathrm{mol}$ of reducing sugar $\mathrm{min}^{-1}(\mathrm{U}) \mathrm{mg}^{-1}$.

Cellobiohydrolase activity of the recombinant proteins was quantified using 4-methylumbelliferyl- $\beta$-D-cellobioside (MUC; Sigma) as a substrate in an assay modified from Ziegelhoffer et al. (2001). Appropriate dilutions of cellulase enzyme were initially made using $0.05 \mathrm{M}$ of sodium acetate $\mathrm{pH} 6.0$ and $0.1 \mathrm{M}$ sodium chloride. One microliter of the dilutions was added into $100 \mu \mathrm{L}$ of MUC reaction buffer in a sealed microtiter plate and incubated for $30 \mathrm{~min}$ at $37^{\circ} \mathrm{C}$. The hydrolysis reaction was terminated by adding $100 \mu \mathrm{L}$ of $0.15 \mathrm{M}$ glycine $(\mathrm{pH} \mathrm{10)}$ ) and the mixture was further incubated at room temperature for $5 \mathrm{~min}$. Relative fluorescence at $460 \mathrm{~nm}$ was measured using an excitation wavelength of $355 \mathrm{~nm}$ (POLARstar Omega, BMG Labtech). A blank was prepared by adding the enzyme to the substrate just prior to the addition of glycine. The activity of the cellulase enzyme was then calculated using a standard curve prepared previously using 4Methylumbelliferone, the product of the MUC hydrolysis reaction. 
The activity of the enzyme was expressed as $\mu \mathrm{mol}$ of $\mathrm{MU} \mathrm{min}{ }^{-1}$ (U) $\mathrm{mg}^{-1}$.

\section{NATIVE CRYSTALLINE CELLULOSE ASSAY}

The substrate, milled stem tissue of Sorghum bicolor (variety MRBuster), was pre-treated in a manner similar to that described in Vancov and McIntosh (2012); with $1 \% \mathrm{H}_{2} \mathrm{SO}_{4}$ for 90 min at $121^{\circ} \mathrm{C}$. Pre-treated material was washed four times with Milli-Q water before use in the method described for CMC. Cellulase enzymes were incubated with the substrate for $20 \mathrm{~h}$ at the optimal $\mathrm{pH}$ and temperature for the respective enzymes. A blank was prepared by adding the enzyme to the substrate just prior to the heating step.
The activity of the cellulase enzyme was expressed as $\mu$ mol of reducing sugar $\min ^{-1}(\mathrm{U}) \mathrm{mg}^{-1}$.

\section{RESULTS}

\section{ENGINEERING OF A GLYCOSYL HYDROLASE ENZYME}

In order to develop a highly active glycosyl hydrolase suitable for production in planta the nucleotide sequence of a highly active endo- $\beta$-1,4-glucanase of microbial origin (a hybrid from Neocallimastix patriciarum and Piromyces sp.), previously codon optimized for plants (Xue et al., 2003) was fused directly to the nucleotide sequence encoding a CBM of plant origin (from tomato SlCel9C1; Figure 1). Native enzymes often contain a Pro/Ser/Thr

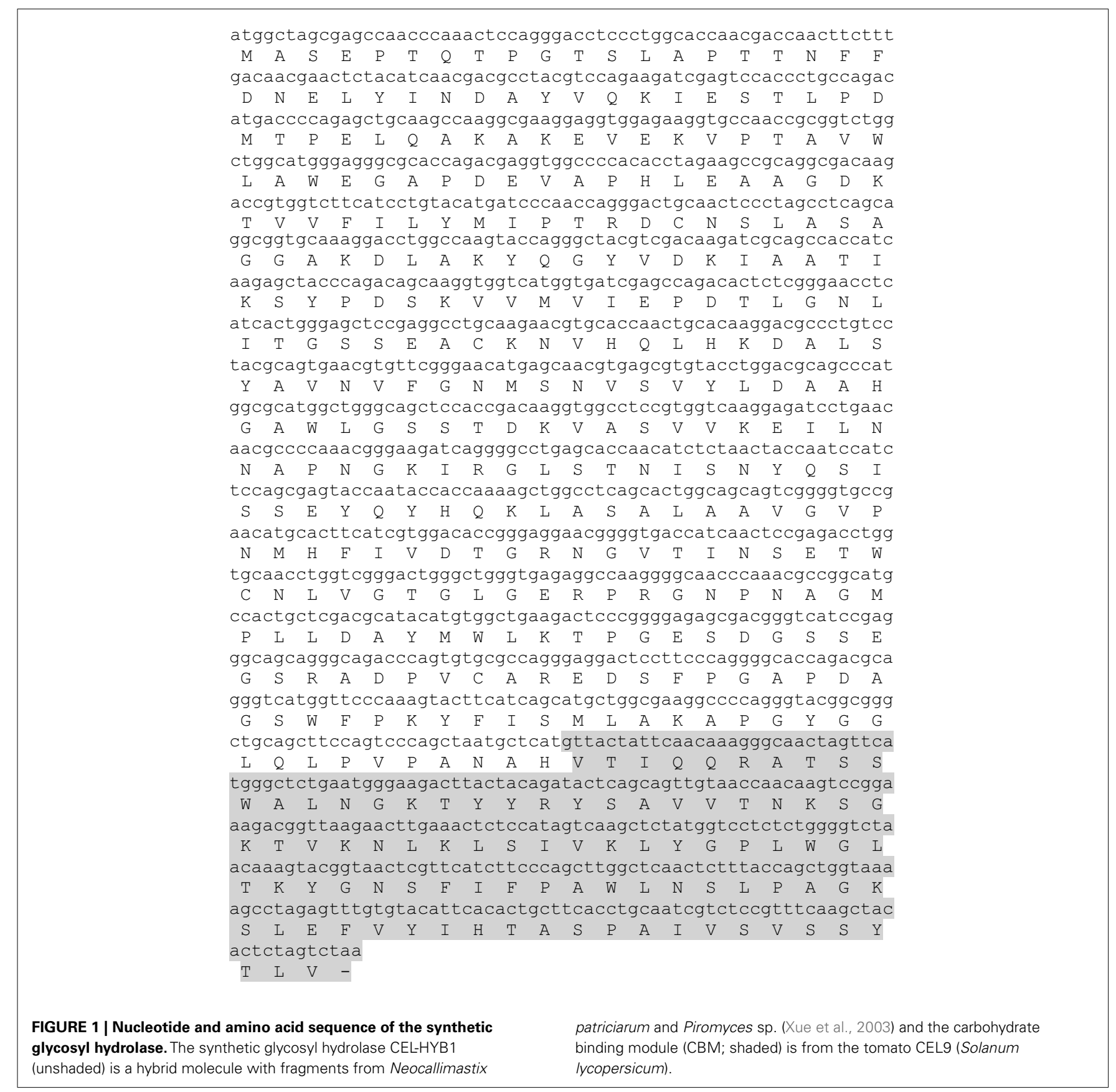


rich linker region between the $\mathrm{CD}$ and the CBMs (Batista et al., 2011); however, no linker region was included between CEL-HYB1 and the CBM in this study.

\section{IN VITRO PRODUCTION OF CEL-HYB1 AND CEL-HYB1-CBM}

CEL-HYB1 and CEL-HYB1-CBM were produced in vitro using a Pichia pastoris expression system. The expression vector used, pPICZ $\alpha$ A containing the methanol inducible $A O X 1$ promoter, secreted heterologous protein (CEL-HYB1 or CEL-HYB-CBM) into the culture supernatant using the $\alpha$-factor signal peptide. Supernatant was concentrated using Centricon Plus ${ }^{\circledR}-70$ columns (Millipore) prior to SDS-PAGE and Coomassie Brilliant Blue staining (Figures 2A,C). Western blotting confirmed the presence of a band corresponding to the CEL-HYB1 at approximately $42 \mathrm{kDa}$ and approximately $55 \mathrm{kDa}$ for CEL-HYB1-CBM (Figures 2B,D). The concentration of CEL-HYB1 protein reached a maximal level at $72 \mathrm{~h}$ whereas CEL-HYB1-CBM protein production was relatively low and efflux to the supernatant peaked $24 \mathrm{~h}$ after methanol induction.

The optimal $\mathrm{pH}$ and temperature conditions for CEL-HYB1 and CEL-HYB1-CBM endo- $\beta$-1,4-glucanase activity were determined using low viscosity $\mathrm{CMC}$ as the substrate and measuring the concentration of reducing sugar produced by the DNS assay (Figures 3A,B). The optimal hydrolysis conditions for the Trichoderma reesei cellulase enzyme cocktail (ATCC26921, Sigma), composed of multiple cellulase enzymes, was also investigated as a comparison (Figures 3A,B). The commercial T. reesei cellulase enzyme mixture contains at least two cellobiohydrolases (CBHI and II), four endo- $\beta$-1,4-glucanases (EGI, II, III, and V), and two $\beta-1,4$ glucosidases (BGLI and II; Seiboth et al., 1997). The cellulase enzyme cocktail derived from $T$. reesei was used as a comparator for the activity of the synthetic cellulase enzymes as cellulases from T. reesei are commonly used in bioethanol production facilities (Margeot et al., 2009).

The hydrolytic activity of CEL-HYB1 and CEL-HYB1-CBM on $\mathrm{CMC}$ was optimal at pH 6.0 (Figure 3B), with almost no endo- $\beta$ 1,4-glucanase activity measured at $\mathrm{pH} 4.0$. The hydrolytic activity of the cellulase enzyme cocktail from $T$. reese $i$ was most active at $\mathrm{pH} 4.8$ and in contrast to the CEL-HYB1 and CEL-HYB1-CBM enzymes, the activity was found to be largely unaffected by $\mathrm{pH}$, especially between $\mathrm{pH} 4.0$ and 5.5 .

Once the optimal pH for CEL-HYB1, CEL-HYB1-CBM, and the $T$. ressei cellulase enzyme cocktail was determined, the effect of temperature on the activity of the enzymes was investigated at optimal pH. The highest CEL-HYB1 and CEL-HYB1-CBM endo$\beta$-1,4-glucanase activity was measured at $37^{\circ} \mathrm{C}$ whereas the $T$. reese $i$ cellulase cocktail demonstrated maximal activity at $60^{\circ} \mathrm{C}$, although stability was evident across a broad temperature range between 50 and $70^{\circ} \mathrm{C}$.

The capacity of CEL-HYB1, CEL-HYB1-CBM, and T. reesei cellulase enzymes to hydrolyze native crystalline cellulose was investigated using pre-treated Sorghum stem material as the substrate and the optimal conditions for each respective enzyme. The T. reesei cellulase enzyme cocktail exhibited the highest hydrolytic capacity $\left(0.105 \mathrm{U} \mathrm{mg}^{-1} \pm 0.018\right)$ followed very closely by CELHYB1-CBM (0.087 $\left.\mathrm{U} \mathrm{mg}^{-1} \pm 0.013\right)$. The CEL-HYB1, however,

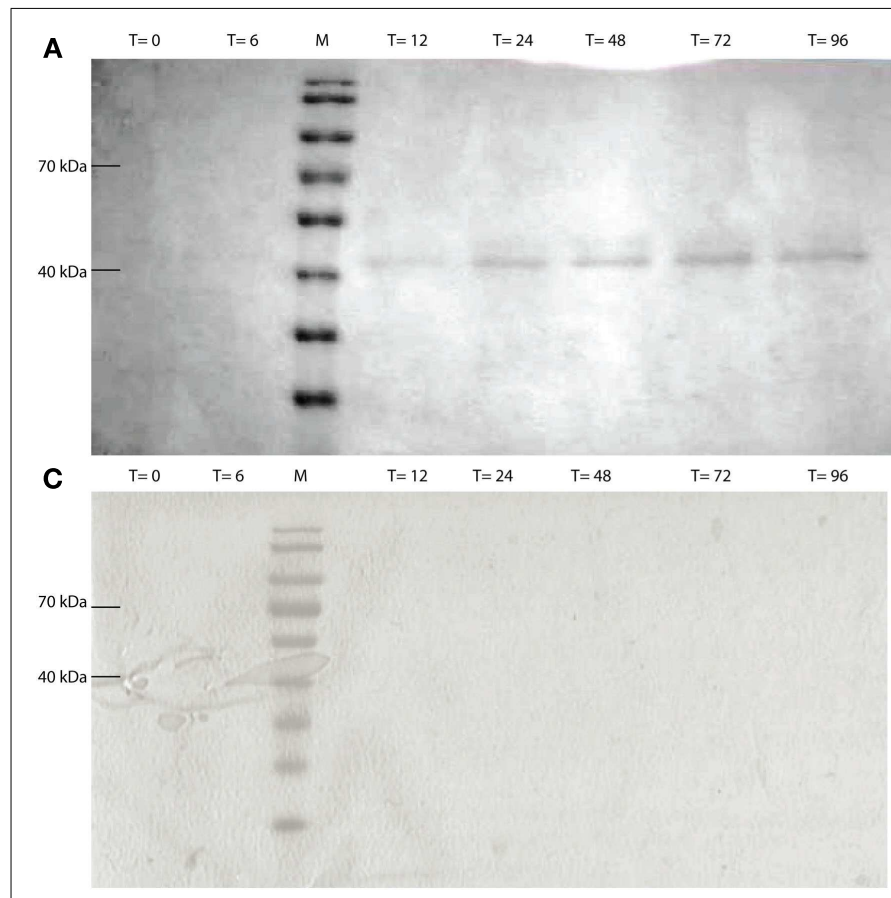

FIGURE 2 | CEL-HYB1 and CEL-HYB1-CBM visualized by SDS-PAGE and Western blotting. Protein production from Pichia pastoris_CEL-HYB1 (A) and P. pastoris_CEL-HYB-CBM (C) induced with $0.5 \%$ methanol; heterologous protein excreted in the supernatant was visualized using SDS-PAGE and Coomassie Brilliant Blue staining.

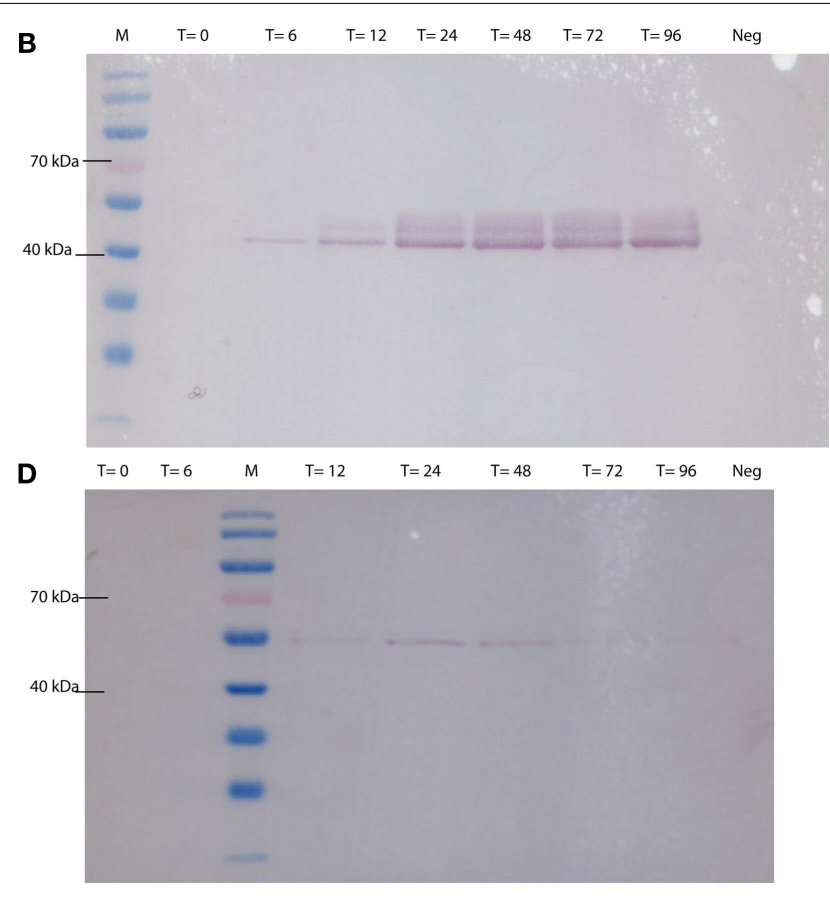

Production of CEL-HYB1 (B) and CEL-HYB1-CBM (D) was confirmed by Western blot with the C-myc antibody. Culture supernatant was harvested at the specified times $(T=0,6,12,24,48,72$, and $96 \mathrm{~h}$; $\mathrm{Neg}=$ negative control; $\mathrm{M}=$ PageRuler $^{\mathrm{TM}}$, Fermentas) after induction with $0.5 \%$ methanol. 

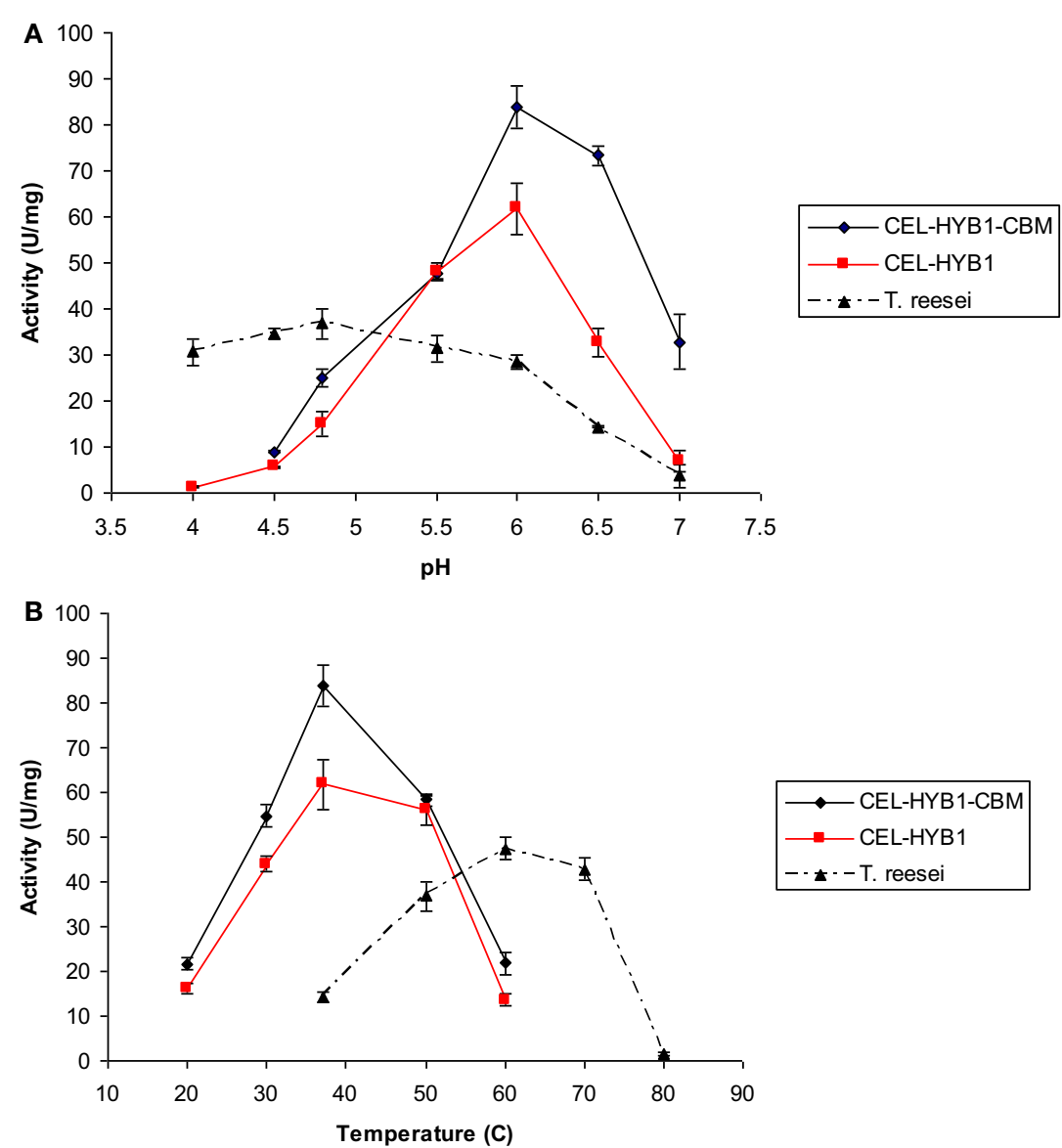

FIGURE 3 | CEL-HYB1 and CEL-HYB1-CBM enzyme activity at varying temperature and $\mathbf{p H}$. Effects of $\mathrm{pH}(\mathbf{A})$ and temperature (B) on the endo- $\beta-1,4$-glucanase activity of CEL-HYB1,

CEL-HYB1-CBM, and T. reesei cellulase enzymes. Measurements shown in (A) were performed at $37^{\circ} \mathrm{C}$ for CEL-HYB1 and
CEL-HYB1-CBM, and $50^{\circ} \mathrm{C}$ for the T. reesei cellulase cocktail. (B) Measurements were obtained using optimal $\mathrm{pH}$ for each enzyme as shown in (A). Measurements were performed in triplicate. The activity is expressed as $\mu \mathrm{mol}$ of reducing sugar $\mathrm{min}^{-1}(\mathrm{U}) \mathrm{mg}^{-1}$. The error bars represent standard deviation. showed very low hydrolytic activity $\left(0.013 \mathrm{U} \mathrm{mg}^{-1} \pm 0.002\right)$, indicating that without the CBM the enzyme was not very efficient in hydrolyzing crystalline cellulose (Figure 4A).

In addition to the CMC and pre-treated sorghum assay, an MUC assay was also performed to investigate the capacity of the CEL-HYB1 and CEL-HYB1-CBM enzymes to cleave the $\beta-1,4$ bonds located at the end of the polysaccharide chain (Schwarz et al., 1987). The assays were performed at $37^{\circ} \mathrm{C}$ and $\mathrm{pH}$ 6.0. The exo-glucanase activity was then directly compared to the exo-glucanase activity of the $T$. reesei cellulase enzyme cocktail measured under the same conditions. The CEL-HYB1 and CEL-HYB1-CBM MUC activity was calculated to be $0.0019 \pm 0.00015$ and $0.0072 \pm 0.001 \mathrm{U} \mathrm{mg}^{-1}$, respectively, whereas the MUC activity of the $T$. reesei cellulase enzyme cocktail was determined to be $0.128 \pm 0.023 \mathrm{U} \mathrm{mg}^{-1}$ (Figure 4B). The CEL-HYB1-CBM demonstrated almost a fourfold higher exoglucanase activity as compared with the CEL-HYB1, although activity was inconsequential as compared with the T. reesei enzyme cocktail.

\section{DISCUSSION}

\section{PLANT CBM IMPROVES GLYCOSYL HYDROLASE ENZYME ACTIVITY}

The tomato CBM at the C-terminus of the synthetic microbial enzyme, CEL-HYB1, increased the endo- $\beta$-1,4-glucanase activity of the enzyme across a range of temperatures and $\mathrm{pH}$ (Figure 3 ). The presence of the CBM, however, did not shift the hydrolytic characteristics of the enzyme, indicating that the increased CELHYB1-CBM activity may be attributed to the increased enzyme affinity toward the substrate, CMC.

In addition to the CMC assay, the activity of the synthetic enzymes was tested using pre-treated Sorghum plant material. The $\mathrm{CMC}$ assay does not measure the absolute endo- $\beta$-1,4-glucanase activity as the substrate used is non-crystalline cellulose and hence, the assay was used as an indicator of cellulase activity whilst optimizing conditions for the assay. Alternatively, the activity of cellulase enzymes against crystalline cellulose may be tested using the Avicel assay which utilizes microcrystalline cellulose (Avicel) as the substrate (Taylor et al., 2008). For example, the activity of the Ruminococcus albus Cel5 on CMC did not differ 


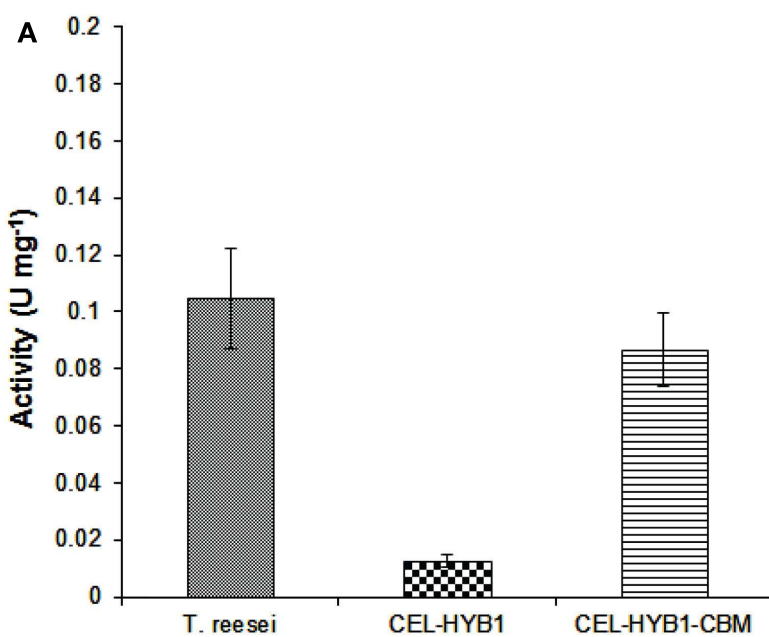

FIGURE 4 | Endo-and exo-glucanase activity of CEL-HYB1 with and without the CBM. The endo- $\beta-1,4-$ glucanase (A) and exo- $\beta-1,4-$ glucanase activity (B) of CEL-HYB1, CEL-HYB1-CBM, and the T. reesei cellulase enzyme cocktail $\left(\mathrm{U} \mathrm{mg}^{-1} \pm \mathrm{SD}\right)$ were compared. Measurements shown in $(\mathbf{A})$ were determined using acid-pre-treated Sorghum material as the substrate, whereas measurements shown in (B) were determined using the MUC assay. The measurements were repeated three times. The activity is

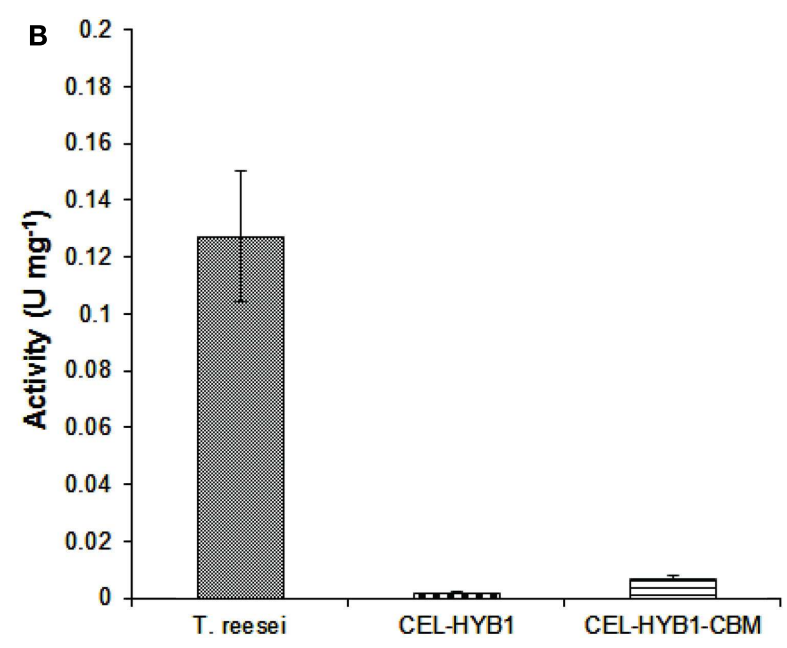

expressed as $\mu \mathrm{mol}$ of reducing sugar $\mathrm{min}^{-1}(U) \mathrm{mg}^{-1}$ for the Sorghum assay, whereas the result of MUC activity assay is expressed as $\mu \mathrm{mol}$ of $\mathrm{MU} \mathrm{\textrm {min } ^ { - 1 }}$ (U) $\mathrm{mg}^{-1}$. The endo- $\beta-1,4-$ glucanase assay was performed at $37^{\circ} \mathrm{C}$ and $\mathrm{pH} 6.0$ for CEL-HYB1 and CEL-HYB1-CBM, whereas for T. reesei, cellulose enzyme measurement was carried out at $60^{\circ} \mathrm{C}$ and $\mathrm{pH}$ 4.8. The MUC assay was performed at $37^{\circ} \mathrm{C}$ and $\mathrm{pH} 6.0$ for all enzymes. Values with the same letters are not different significantly at $P<0.05$ (Fisher's LSD test). significantly when fused with a Clostridium stercorarium CBM yet the activity of the same Cel5:CBM fusion protein on Avicel was enhanced compared to the native Cel5 (Bae et al., 2003). Interestingly, the activity of the Clostridium thermocellum endoglucanase $\left(\mathrm{EGE}_{\mathrm{CD}}\right)$ on CMC did not differ significantly when fused with a Pseudomonas fluorescens cellulose binding domain (CELE $\left.\mathrm{CBD}_{\mathrm{C}}\right)$ or xylanase binding domain $\left(X_{\mathrm{X}} \mathrm{A}_{\mathrm{CBD}}\right)$ yet the activity of the $\mathrm{EGE}_{\mathrm{CD}}$ : $\mathrm{CELE}_{\mathrm{CBD}}$ and $\mathrm{EGE}_{\mathrm{CD}}$ :XYLA $\mathrm{CBD}_{\mathrm{CB}}$ fusion proteins on cotton was significantly enhanced compared to $\mathrm{EGE}_{\mathrm{CD}}$. In this case the activity of the fusion proteins was significantly lower on Avicel relative to $\mathrm{EGE}_{\mathrm{CD}}$ (Bolam et al., 1998). Although the Avicel assay may be a better method to estimate the cellulase activity as compared with the CMC assay, it is still limited as the interaction of cellulases with other plant cell wall components such as lignin, may affect the overall activity of the enzymes and this would not be represented. Thus, the activity of the synthetic enzymes against crystalline sorghum cellulose from pre-treated stem biomass was undertaken to provide an estimate of enzyme activity on native plant cellulose.

In comparison with the CMC assay results, when the acidpre-treated Sorghum plant material was used as the substrate, all of the tested enzymes demonstrated lower endo- $\beta$-1,4-glucanase activity. The CEL-HYB1 had very low activity compared to the T. reesei cellulase cocktail. The presence of the CBM on the CEL-HYB1 improved the activity dramatically such that the endo- $\beta$-1,4-glucanase activity of the fusion protein was similar to that of the $T$. reesei cellulase cocktail. The $T$. reesei cellulase enzyme cocktail was a mixture of several cellulase enzymes which included endo- $\beta$-1,4-glucanase, exo-glucanase, and $\beta$ glucosidase and it has been demonstrated that when present together different cellulase enzymes may have some level of synergism, resulting in improved hydrolytic activity (Irwin et al.,
1993; Hilden and Johansson, 2004). Additionally, all endo- $\beta-1,4-$ glucanase and exo- $\beta$-1,4-glucanase enzymes derived from $T$. reese $i$ are reported to have CBMs and hence the enzymes would be expected to catalyze increased hydrolytic activity (Takashima et al., 1998).

\section{ENZYME ACTIVITY ON PLANT BIOMASS DIFFERS FROM ACTIVITY ON COMMERCIAL CELLULOSE}

CEL-HYB1-CBM is active against the Sorghum crystalline cellulose as is; however, mixing of the enzyme with exo-glucanase and $\beta$-glucosidase is likely to improve the activity further. The stark differences between the results of the CMC assay compared with the use of pre-treated sorghum as a substrate simply highlight the inadequacy of the CMC assay as a tool to predict cellulase activity against crystalline cellulose.

The increase in CEL-HYB1-CBM activity can be attributed to the presence of the CBM which potentiates the binding capability of the enzyme to crystalline cellulose. This assertion is supported by data presented previously demonstrating that the CBM of SlCel9C1 is able to bind to crystalline cellulose (Urbanowicz et al., 2007). Previous reports have shown that cellulase activity against non-soluble cellulose could be increased significantly by adding a microbial CBM to the enzyme (Bae et al., 2003; Moses et al., 2005; Mahadevan et al., 2008).

\section{ENGINEERING MORE ACTIVE ENZYMES}

The results of the CMC and sorghum hydrolysis indicate that a CBM originating from an endogenous plant cellulase can have a positive impact on the hydrolytic capacity of the enzyme. An earlier attempt to increase the enzyme hydrolytic capability by attaching the CBM of SlCel9C1 to the C-terminus of TfCel6A, an endo- $\beta$ 1,4-glucanase from Thermobifida fusca, failed as the fusion protein 
demonstrated lower activity as compared with the native enzyme (Urbanowicz et al., 2007). This was hypothesized to be caused by the configuration of the fusion protein, whereby the CBM module separated the $\mathrm{CD}$ of the enzyme from the substrate (Urbanowicz et al., 2007). The results presented herein demonstrate that the presence of the CBM at the C-terminus of CEL-HYB1 did not hinder the binding of the substrate to the active site of the cellulase even though no linker region between the two domains was present.

As native plant cellulase enzymes are involved in re-modeling the cell wall during growth it is likely that there is great variation in the substrate affinity within plant CBMs. As mixtures of cellulase enzymes can have synergistic effects (Irwin et al., 1993), the impact of fusing various plant CBMs to a range of highly active endo- and exo-glucanases and assessing the activity of different mixtures of these fusion proteins would be of interest.

As demonstrated here, the activity of cellulases may be altered by recombining regions of natural cellulase homologs. This approach was also used to demonstrate the importance of a CBM

\section{REFERENCES}

Bae, H.-J., Turcotte, G., Chamberland, H., Karita, S., and Vezina, L.-P. (2003). A comparative study between an endoglucanase IV and its fused protein complex Cel5CBM6. FEMS Microbiol. Lett. 227, 175-181.

Batista, P. R., de Souza Costa, M. G., Pascutti, P. G., Bisch, P. M., and de Souza, W. (2011). High temperatures enhance cooperative motions between CBM and catalytic domains of a thermostable cellulase: mechanism insights from essential dynamics. Phys. Chem. Chem. Phys. 13, 13709-13720.

Beckham, G. T., Dai, Z., Matthews, J. F., Momany, M., Payne, C. M., Adney, W. S., et al. (2012). Harnessing glycosylation to improve cellulase activity. Curr. Opin. Biotechnol. 23, 338-345.

Bolam, D. N., Ciruela, A., McQueenMason, S., Simpsons, P., Williamson, M. P., Rixon, J. E., et al. (1998). Pseudomonas cellulose-binding domains mediate their effects by increasing enzyme substrate proximity. Biochem. J. 331, 775-781.

Caparrós, C., Lant, N., Smets, J., and Cavaco-Paulo, A. (2012). Effects of adsorption properties and mechanical agitation of two detergent cellulases towards cotton cellulose. Biocatal. Biotransformation 30, 260-271.

Cheng, G., Liu, Z., Murton, J. K., Jablin, M., Dubey, M., Majewski, J., et al. (2011). Neutron reflectometry and QCM-D study of the interaction of cellulases with films of amorphous cellulose. Biomacromolecules 12, 2216-2224.

Ghose, T. K. (1987). Measurement of cellulase activity. Pure Appl. Chem. $59,257-268$.

Hilden, L., and Johansson, G. (2004). Recent development on cellulases and carbohydrate-binding module with cellulose affinity. Biotechnol. Lett. 26, 1683-1693.

Irwin, D. C., Spezio, M., Walker, L. P., and Wilson, D. B. (1993). Activity studies of eight purified cellulases: specificity, synergism and binding domain effects. Biotechnol. Bioeng. 42, 1002-1013.

Kostylev, M., Moran-Mirabal, J. M., Walker, L. P., and Wilson, D. B. (2011). Determination of the molecular states of the processive endocellulase Thermobifida fusca Cel9A during crystalline cellulose depolymerisation. Biotechnol. Bioeng. 109, 295-299.

Linder, M., and Teeri, T. T. (1997). The roles and function of cellulosebinding domains. J. Biotechnol. 57, $15-28$.

Louime, C., and Uckelmann, H. (2008). Potential and prospects of cellulosic ethanol in the world. Curr. Sci. 94, 1567-1568.

Mahadevan, S. A., Wi, S. G., Lee, D.-S., and Bae, H.-J. (2008). Site-directed mutagenesis and $\mathrm{CBM}$ engineering of Cel5A (Thermotoga maritima). FEMS Microbiol. Lett. 287, 205-211.

Margeot, A., Hahn-Hagerdal, B., Edlund, M., Slade, R., and Monot, F. (2009). New improvements for lignocellulosic ethanol. Curr. Opin. Biotechnol. 20, 1-9.

to the thermal stability of a family 9 cellulase (Mingardon et al., 2011). An alternative option for increasing the activity of cellulase enzymes may involve mutating the linker region between the $C D$ and the CBM so as to alter the flexibility; this may influence conformational changes and thus activity (Batista et al., 2011). There is also much to learn about the impact of glycosylation on the function of CBMs (Beckham et al., 2012). CBMs and their linkers may have $\mathrm{O}$-glycans attached, whereas the $\mathrm{CD}$ may have $\mathrm{N}$-glycans attached; these glycans may interact directly with the cellulose and impact binding affinity (Beckham et al., 2012). Thus, modifying cellulose enzyme and CBM glycosylation may be another avenue toward improving enzyme activity.

\section{ACKNOWLEDGMENTS}

We wish to thank the Australian Research Council (ARC) for their financial support (Caitlin S. Byrt and Christopher P. L. Grof were supported under ARC's Discovery Projects funding scheme (project number LP0883808). We thank Natalie Kibble for the kind gift of Pichia cultures and expression vector and we thank Dr Tony Vancov for the kind gift of the pretreated sorghum material.

Medie, F. M., Davies, G. J., Drancourt, M., and Henrissat, B. (2012). Genome analyses highlight the different biological roles of cellulases. Nat. Microbiol. 10, 227-234.

Miller, G. L. (1959). Use of dinitrosalicylic acid reagent for determination of reducing sugar. Anal. Chem. 31, 426-328.

Mingardon, F., Bagert, J. D., Maisonnier, C., Trudeau, D. L., and Arnold, F. H. (2011). Comparison of family 9 cellulases from mesophilic and thermophilic bacteria. Appl. Environ. Microbiol. 77, 1436-1442.

Moses, S. B. G., Otero, R. R. C., and Pretorius, I. S. (2005). Domain engineering of Saccharomyces cerevisiae exoglucanases. Biotechnol. Lett. 27, 355-362.

Schwarz, W. H., Bronnenmeier, K., Grabnitz, F., and Staudenbauer, W. L. (1987). Activity staining of cellulases in polyacrylamide gels containing mixed linkage $\beta$-glucans. Anal. Biochem. 164, 72-77.

Seiboth, B., Hakola, S., Mach, R. L., Suominen, P. L., and Kubicek, C. P. (1997). Role of four major cellulases in triggering of cellulase gene expression by cellulose in Trichoderma reesei. J. Bacteriol. 179, 5318-5320.

Takashima, S., Iikura, H., Nakamura, A., Hidaka, M., Masaki, H., and Uozumi, T. (1998). Overproduction of recombinant Trichoderma reesei cellulases by Aspergillus oryzae and their enzymatic properties. J. Biotechnology 65, 163-171.

Taylor, L. E., Dai, Z., Decker, S. R., Brunecky, R., Adney, W. S., Ding, S.-Y., et al. (2008). Heterologous expression of glycosyl hydrolases in planta: a new departure for biofuels. Trends Biotechnol. 26, 413-424.

Urbanowicz, B. R., Catalá, C., Irwin, D., Wilson, D. B., Ripoll, D. R., and Rose, J. K. C. (2007). A tomato endo-beta1,4-glucanase, SlCel9C1, represents a distinct subclass with a new family of carbohydrate binding modules (CBM49). J. Biol. Chem. 282, 12066-12074.

Vancov, T., and McIntosh, S. (2012). Mild acid pretreatment and enzyme saccharification of Sorghum bicolor straw. Appl. Energy 92, 421-428.

Wilson, D. B. (2012). Processive and nonprocessive cellulases for biofuel production - lessons from bacterial genomes and structural analysis. Appl. Microb. Biotechnol. 93, 497-502.

Wolfenden, R., and Snider, M. J. (2001). The depth of chemical time and the power of enzymes as catalysts. Acc. Chem. Res. 34, 938-945.

Xue, G. P., Patel, M., Johnson, J. S., Smyth, D. J., and Vickers, C. E. (2003). Selectable marker-free transgenic barley producing a high level of cellulase ( $1,4-\beta$-glucanase $)$ in developing grains. Plant Cell Rep. 21, 1088-1094.

Yin, Q., Teng, Y., Ding, M., and Zhao, F. (2011). Site-directed mutagenesis of aromatic residues in the carbohydrate-binding module of Bacillus endoglucanase EGA decreases enzyme thermostability. Biotechnol. Lett. 33, 2209-2216. 
Ziegelhoffer, T., Raasch, J. A., and Austin-Phillips, S. (2001). Dramatic effects of truncation and sub-cellular targeting on the accumulation of recombinant microbial cellulase in tobacco. Mol. Breed. 8, 147-158.

Conflict of Interest Statement: The authors declare that the research was conducted in the absence of any commercial or financial relationships that could be construed as a potential conflict of interest.

Received: 04 July 2012; accepted: 29 October 2012; published online: 19 November 2012.
Citation: Byrt CS, Cahyanegara $R$ and Grof CPL (2012) Plant carbohydrate binding module enhances activity of hybrid microbial cellulase enzyme. Front. Plant Sci. 3:254. doi: 10.3389/fpls.2012.00254

This article was submitted to Frontiers in Plant Biotechnology, a specialty of Frontiers in Plant Science.
Copyright (C) 2012 Byrt, Cahyanegara and Grof. This is an open-access article distributed under the terms of the Creative Commons Attribution License, which permits use, distribution and reproduction in other forums, provided the original authors and source are credited and subject to any copyright notice concerning any third-party graphics etc. 